\title{
Wat is juridisch interactionisme? ${ }^{*}$
}

\author{
Wibren van der Burg
}

\section{Het tekortschieten van de rechtsfilosofie}

Vijfentwintig jaar geleden deed ik als ethicus en rechtsfilosoof in Utrecht onderzoek op het terrein van bio-ethiek en gezondheidsrecht. Dit was een merkwaardig en spannend terrein. Er was nauwelijks positief recht in de vorm van wetgeving of jurisprudentie. Juristen en ethici werkten nauw samen om voor nieuwe problemen theoretisch bevredigende oplossingen te vinden. Maar de rechtsontwikkeling en de moraalontwikkeling vonden vooral plaats in de praktijk, waar zich in de professionele praktijk geleidelijk nieuwe normen uitkristalliseerden. In die praktijk, maar ook in de wetenschap waren moraal en recht sterk verstrengeld. Een treffend voorbeeld daarvan is dat rond een omstreden onderzoeksproject met HIV-testen de gezondheidsjurist Gevers en ik als ethicus op een symposium vrijwel gelijkluidende analyses hadden. Toen ik bij een vervolgbijeenkomst zowel het juridische als het ethische perspectief moest presenteren, kostte het geen enkele moeite beide in elkaar te schuiven. ${ }^{1}$ De titel van het boek dat Pieter Ippel en ik in 1994 redigeerden, biedt een duidelijke metafoor voor deze verstrengeling van recht en moraal: De Siamese tweeling. ${ }^{2}$

Toen ik in de rechtsfilosofische literatuur dook om die dynamische verstrengeling van recht en moraal beter te begrijpen, werd ik echter teleurgesteld. De sourcebased versies van het rechtspositivisme bijvoorbeeld bieden weinig houvast in situaties waarin nauwelijks rechtsbronnen bestaan en waarin het recht meer gap dan texture is en bovendien sterk op morele argumentaties rust. Een onderscheid, laat staan een scheiding, tussen recht en moraal was gewoon niet te maken. Natuurrechtelijke theorieën kwamen natuurlijk voor in de discussies over abortus en euthanasie, maar waren zo controversieel dat de hoop op breed aanvaardbare grondslagen naïef leek. Bovendien waren natuurrechtdenkers al evenzeer op zoek naar antwoorden voor de volstrekt nieuwe problemen rond bijvoorbeeld gentechnologie. En mijn toenmalige eigen favoriet, Ronald Dworkin, bood misschien een bruikbaar kader in contexten waarin rechtsontwikkeling het gevolg is van rechterlijke activiteit en wetgeving, maar niet voor situaties waarin rechtsont-

* $\quad$ Dit is een bewerking van een voordracht gehouden op 3 februari 2012 voor de wintervergadering van de Vereniging voor Wijsbegeerte van het Recht (VWR) in Maastricht; ik heb de wat informele en persoonlijke stijl van de lezing proberen te behouden. Ik dank de aanwezigen voor de stimulerende discussie. Bijzondere dank gaat uit naar de referenten Paul de Hert, Jelle Oud en Reijer Passchier, naar Jaap Hage, Thomas Riesthuis en Bert-Jan Wolthuis voor commentaar op een eerdere versie en naar mijn student-assistente Astrid van der Wal voor haar ondersteuning.

1 Wibren van der Burg, 'Breed onderzoek HIV-prevalentie zonder "informed consent" strijdig met Grondwet,' Stcrt. 2 december 1988, 7 en 10.

2 Wibren van der Burg en Pieter Ippel, red., De Siamese tweeling. Recht en moraal in de biomedische praktijk (Assen: Van Gorcum, 1994). 
wikkeling niet primair binnen juridische instituties plaatsvindt maar vooral in de praktijk van de gezondheidszorg en in maatschappelijke discussies. Zijn idee dat recht en moraal met elkaar verbonden waren, paste natuurlijk goed bij de verstrengeling van gezondheidsrecht en bio-ethiek. Maar door zijn sterke focus op de rechter had hij een blinde vlek voor rechtsontwikkeling buiten de officiële juridische instituties. Zijn normatieve theorie over rechten bood in discussies over euthanasie, abortus, gentechnologie en dierexperimenten overigens ook al onvoldoende nuance. ${ }^{3}$

Gelukkig bood de rechtssociologie wel bruikbare vertrekpunten met auteurs als Philip Selznick en theorieën rond rechtspluralisme. Maar het bleef knagen dat de grote theorieën van de rechtsfilosofische canon tekortschoten in een adequate conceptualisering van wat er in gezondheidsrecht en bio-ethiek aan de hand was. Dat gevoel werd sterker toen ik me vervolgens bezig ging houden met verschijnselen als communicatieve of interactieve wetgeving, en met internationaal recht - ook verschijnselen die niet goed in grote delen van de canon zijn in te passen. Het boek dat ik dit jaar heb afgerond, is een poging om op deze teleurstellende ervaringen een antwoord te vinden. ${ }^{4}$ In dit artikel presenteer ik de hoofdlijnen van die theorie van recht die als 'juridisch interactionisme' kan worden aangeduid.

\section{Theoretisch pluralisme en wederzijds onbegrip in de rechtsfilosofie}

Natuurlijk had ik meteen een eigen theorie van recht en moraal kunnen ontwikkelen, en die zal ik in dit artikel ook uiteenzetten. Maar er was nog een tweede punt dat ik onbevredigend vond in de rechtsfilosofische discussies over recht en moraal. Dat is dat de auteurs voortdurend langs elkaar heen praten - ze lijken elkaar echt niet te begrijpen. Rond het werk van Dworkin is dat natuurlijk een bekend probleem. Een substantieel deel van zijn werk richt zich erop om aan te geven waarom zijn critici hem niet hebben begrepen en een karikatuur van zijn werk hebben gemaakt; terwijl omgekeerd, in de ogen van zijn critici, hij steeds een karikatuur van hún werk maakt. In Nicola Laceys prachtige biografie van Hart zie je dat ook Hart tot het eind van zijn leven is blijven worstelen niet alleen om een

3 Het was dan ook niet verwonderlijk dat in zijn latere boek over bio-ethische vragen hij het rechtendiscours grotendeels verliet en zich vooral richtte op waarden - m.i. inderdaad een vruchtbaarder invalshoek om over veel bio-ethische kwesties na te denken. Zie Ronald Dworkin, Life's Dominion. An Argument about Abortion, Euthanasia, and Individual Freedom (New York: Alfred A. Knopf, 1993); Wibren van der Burg, 'Legislation on Human Embryos. From Status Theories to Value Theories,' Archiv für Rechts- und Sozialphilosophie 82 (1996): 73.

4 Wibren van der Burg, The Dynamics of Law and Morality. A Pluralist Account of Legal Interactionism (Farnham: Ashgate, 2014, ter perse). Sommige gedeelten in dit artikel zijn ontleend aan het boek. Omdat ik in dit artikel de ideeën van een heel boek samenvat, kan ik onmogelijk alle nuances recht doen en overal overtuigende argumenten voor mijn stellingen bieden. Dit artikel presenteert vooral de hoofdlijnen van mijn theorie in het tweede deel van het boek; voor een verdere uitwerking en argumentatie verwijs ik de lezer naar dit boek. 
antwoord op Dworkin te vinden, maar zelfs om hem te begrijpen. ${ }^{5}$ En in het HartFuller-debat is er bij beide kampen vertwijfeling en irritatie om het wederzijdse onbegrip. ${ }^{6}$

Hoe kan het dat zelfs de grote geesten van de rechtsfilosofie niet in staat zijn om elkaar echt te begrijpen? Voordat we weer een nieuwe theorie van recht en moraal toevoegen aan de grote verzameling van dergelijke theorieën, is daarop een antwoord nodig. Het antwoord op die vraag ontwikkel ik in de eerste helft van het boek, en vat ik hier alleen even samen om het hoofdthema van dit artikel in de juiste context te plaatsen. De verklaring is tweeledig. Het recht is zowel een wezenlijk ambigu begrip als een wezenlijk betwist begrip, waardoor een onoverbrugbare pluraliteit aan theorieën van recht niet alleen onvermijdelijk, maar ook legitiem is. Het is wezenlijk ambigu (essentially ambiguous) omdat er ten minste twee modellen zijn van recht - recht als praktijk en recht als product - die niet helemaal tot elkaar te herleiden zijn. ${ }^{7}$ En het is wezenlijk betwist (essentially contested), omdat recht een op waarden of idealen gericht verschijnsel is en zowel de invulling van die idealen als de onderlinge verhouding ervan betwist is en dus tot meerdere invullingen kan leiden. ${ }^{8}$ Deze formulering moet bovendien nog worden aangevuld en gepreciseerd, want het gaat hier om een wezenlijk betwist zijn van de tweede orde: het is ook wezenlijk betwist of recht wel een op waarden gericht

5 Nicola Lacey, A Life of H.L.A. Hart. The Nightmare and the Noble Dream (Oxford: Oxford University Press, 2004).

6 Voor voorbeelden van die klachten dat ze de tegenpartij in het debat niet goed begrijpen en door hem niet goed worden begrepen, zie Lacey, Life of H.L.A. Hart, 198 (verwijzend naar een brief van Hart waarin hij Fullers antwoord op zijn beroemde Holmes lecture aanduidt als een zeer onduidelijk 'piece of logomachy'); H.L.A. Hart, 'Book review of The Morality of Law,' Harvard Law Review 78 (1965): 1281; Lon L. Fuller, The Morality of Law (New Haven: Yale University Press, 1969 [1964]), 154 ('I must confess I am puzzled by it.' - verwijzend naar Harts kritiek); H.L.A. Hart, Postscript in The Concept of Law (Oxford: Clarendon, 1994 [1961]) (waarin hij verwijzend naar Dworkins interpretatie en kritiek termen gebruikt als 'perplexing' (243), 'tantalizingly obscure' (257)); Ronald Dworkin, Justice in Robes (Cambridge, MA: Belknap Press, 2006), 166 (stellend dat hij alleen maar kan vasthouden aan zijn eigen interpretatie van Harts theorie, ondanks Harts eigen expliciete ontkenning dat dit een juiste interpretatie is). In feite zijn grote delen van het laatste boek (en van andere publicaties van zijn hand) gewijd aan Dworkins eigen betoog dat bepaalde auteurs, zoals Hart en Coleman, zijn theorie compleet misverstaan hebben. Op zijn beurt presenteert Dworkin, zoals ook in eerdere boeken en artikelen, de opvattingen van zijn opponenten vaak weer op manieren waarin zij zichzelf moeilijk kunnen herkennen. Zie ook Nicola Lacey, 'Out of the Witches' Cauldron? Reinterpreting the Context and Re-assessing the Significance of the Hart-Fuller Debate,' in The Hart-Fuller Debate in the Twenty-First Century, red. Peter Cane (Oxford: Hart Publishing, 2010), 23, waarin zij beschrijft hoe Fuller meende dat zijn werk algemeen onjuist werd uitgelegd; dit is ook een terugkerend thema in Rundles intellectuele biografie van Fuller (Kristen Rundle, Forms Liberate. Reclaiming the Jurisprudence of Lon L. Fuller (Oxford: Hart Publishing, 2012)).

7 Dit punt heb ik eerder uitgewerkt in Wibren van der Burg, 'Essentially Ambiguous Concepts and the Fuller-Hart-Dworkin Debate,' Archiv für Rechts- und Sozialphilosophie 95 (2009): 305. Ik maak daar onderscheid tussen een productmodel en een praktijkmodel van recht.

8 Vgl. bijv. Philip Selznick, 'Sociology and Natural Law,' Natural Law Forum 6 (1961): 84; Fuller, Morality of Law; Dworkin, Justice in Robes, 221: 'Lawyers share the concept of law as what I call an interpretive (or essentially contested) concept.' 
verschijnsel is. Volgens de meeste positivisten is het dat niet, volgens anderen wel. ${ }^{9}$

Het inzicht dat recht een wezenlijk ambigu begrip is, kan veel van het wederzijds onbegrip van rechtsfilosofische auteurs verklaren: ze hanteren verschillende modellen van recht en praten dus langs elkaar heen. Het inzicht dat recht een tweede orde wezenlijk betwist begrip is, kan vooral verklaren waarom er niet één definitie van 'the distinctively legal' mogelijk is. Volgens sommigen is het recht een neutraal begrip, volgens anderen kan het alleen gezien worden in het licht van fundamentele waarden - en daarbij verschillen de auteurs weer, zoals te verwachten is bij een wezenlijk betwist begrip, ${ }^{10}$ over wat die waarden inhouden en hoe ze zich tot elkaar verhouden.

Mijn conclusie is dat theoretisch pluralisme, dat wil zeggen een pluralisme van theorieën over recht, onvermijdelijk is. Eén universele coherente theorie van recht is namelijk onmogelijk vanwege dit wezenlijk ambigue en wezenlijk betwiste karakter. Bovendien is het in het licht van de grote verscheidenheid aan rechtsordes, van het recht in tribale gemeenschappen tot het internationaal recht, en van het gewoonterecht tot het sterk gecodificeerde en geïnstitutionaliseerde Nederlandse recht anno 2014, niet waarschijnlijk dat, als er al gemeenschappelijke minimale eigenschappen geconstrueerd zouden kunnen worden (wat ik dus betwist), deze voldoende substantieel zouden zijn om echt interessant te zijn. We kunnen daarom alleen gedeeltelijk adequate theorieën van recht ontwikkelen voor specifieke rechtsordes in specifieke contexten. ${ }^{11}$ Sommige onderdelen daarvan zullen vrij algemeen geldig zijn en bijvoorbeeld gelden voor alle westerse democratieën of zelfs voor alle rechtsordes met codificaties, andere onderdelen zijn meer specifiek en gelden alleen voor Nederland anno 2014. Dergelijke theorieën kunnen echter nooit volledig adequaat zijn; ze verwaarlozen altijd bepaalde aspecten van het recht.

9 Zowel de pragmatist Philip Selznick als de rechtspositivist Gustav Radbruch (ook al in zijn vroege positivistische werk) zien het recht als wezenlijk gericht op idealen of waarden. Vgl. hierover Sanne Taekema, The Concept of Ideals in Legal Theory (Den Haag: Kluwer Law International, 2003). Zie ook Wibren van der Burg en Sanne Taekema, red., The Importance of Ideals. Debating Their Relevance in Law, Morality, and Politics (Brussel, enz.: Peter Lang, 2004). De meeste rechtspositivisten ontkennen echter dat het recht alleen kan worden begrepen als een op waarden gericht verschijnsel.

10 Sinds Gallie de uitdrukking essentially contested concepts introduceerde, is zij te pas en te onpas gebruikt. (Walter B. Gallie, 'Essentially Contested Concepts,' Proceedings of the Aristotelian Society 56 (1956): 167). Cruciaal voor Gallies theorie is dat het gaat om evaluerende (appraisive), aspiratieve en complexe begrippen. Verschillende invullingen (in Dworkins terminologie: conceptions) benadrukken verschillende waarden of zien de onderlinge verhouding tussen die waarden verschillend.

11 Een dergelijke principieel pluralistische en contextualistische benadering van theorieën van recht sluit aan op zowel Selznicks als Fullers contextualisme. Vgl. Rundle, Forms Liberate, 6: '[Fuller] never suggested that his claims were to be accepted as universally applicable, in the style of general jurisprudence.' Vgl. ook Roger Cotterrell, The Politics of Jurisprudence. A Critical Introduction to Legal Philosophy (Londen en Edinburgh: LexisNexis, 2003), 254. 
Volgens Julie Dickson dient de analytische rechtsfilosofie de wezenskenmerken van het recht te bestuderen: 'those essential properties which a given set of phenomena must exhibit in order to be law. ${ }^{12}$ Een dergelijke zoektocht naar 'the distinctively legal' gaat dus naar mijn overtuiging uit van een verkeerd uitgangspunt, omdat zij op zoek is naar iets wat niet gevonden kán worden. Natuurlijk kan zij net als de zoektocht naar de Heilige Graal of de Steen der Wijzen interessante bijproducten opleveren. De zoektocht heeft tal van interessante suggesties opgeleverd van kenmerken van recht die in veel rechtsordes aanwezig zijn en voor het begrijpen van deze rechtsordes van wezenlijk belang zijn, zoals de verbondenheid met een staatsapparaat, de aanwezigheid van sancties en van secundaire regels enzovoort. Maar zij heeft geen universele kenmerken opgeleverd die door een meerderheid van rechtstheoretici worden aanvaard, en mijn theoretisch kader verklaart waarom dit niet gelukt is.

In plaats van ons op mogelijke essentiële eigenschappen van het recht te richten, dienen we de rijke verscheidenheid van rechtsordes te bestuderen met een open oog voor variatie, voor de specifieke contexten en voor de dynamiek in die rechtsordes. De zoektocht naar het universele en essentiële verwaarloost niet alleen de particuliere eigenschappen die een concreet rechtssysteem karakteriseren, maar ook de relatief algemene eigenschappen die in veel - zij het niet in alle - rechtsordes voorkomen. In plaats van alle juridische verschijnselen in een Procrustesbed van essentiële eigenschappen te leggen, moeten we ons op het pluralisme en de dynamiek van die verschijnselen richten. In paragraaf 5 ga ik verder in op wat dit betekent voor het rechtsbegrip en zal ik bepleiten dit te zien in termen van een dynamische familiegelijkenis. Maar eerst ga ik in op de rechtstheorie.

\section{Eisen aan een adequate rechtstheorie in de actuele Nederlandse context}

De vraag naar het rechtsbegrip dient dus niet te zijn: wat is de enig juiste universele theorie van recht? We dienen ons te richten op een andere vraag, namelijk: wat is de meest adequate theorie van recht voor een specifieke context? Ik pretendeer dus ook niet een universele theorie van recht en moraal te geven; dat is immers niet goed mogelijk. De context waarop mijn theorie zich primair richt, is die van westerse democratische rechtsstaten aan het begin van de $21^{\text {ste }}$ eeuw. ${ }^{13}$ Dat sluit niet uit dat veel ervan ook in andere contexten geldig kan zijn - hopelijk is dit juist wel het geval - maar om ook aan alle variaties in context recht te doen zou mijn theorie hopeloos complex of extreem vaag worden.

Hoe kunnen we bepalen wat de meest adequate theorie voor de gekozen context is? Een minimale eis voor een adequate theorie lijkt me dat zij de belangrijkste

12 Julie Dickson, Evaluation and Legal Theory (Oxford \& Portland: Hart Publishing, 2001), 17. Vgl. ook Scott Shapiro, Legality (Cambridge, MA: Belknap Press, 2011), Chapter 1.

13 Mijn perspectief is dus, in de woorden van William Twining, 'self-consciously quite parochial, reflecting my own biases and limited knowledge.' (William Twining, General Jurisprudence. Understanding Law from a Global Perspective (Cambridge: Cambridge University Press, 2009), xiii.) 
specifieke verschijnselen en kenmerken van die context kan inpassen. Daarbij gaat het me overigens niet om een compleet beeld maar om de knelpunten: die kenmerken waar gangbare theorieën van recht mee worstelen. Wanneer je de analyse op die knelpunten richt, krijg je de lacunes van het huidige rechtsfilosofische debat het beste in beeld. Op basis daarvan kun je dan, deels voortbouwend op bestaande theorieën, een nieuwe theorie van recht construeren die voor die knelpunten een oplossing biedt. Zo'n theorie is dan vanuit dat gezichtspunt adequater dan de bestaande theorieën. Het recht in de $21^{\text {ste }}$ eeuw kent m.i. ten minste vier van dergelijke knelpunten, dus verschijnselen waarmee sommige rechtsfilosofische theorieën niet goed raad weten. ${ }^{14}$

\section{De enorme groei van het geschreven recht}

De regulatory explosion is moeilijk te missen; er is een onoverzienbare, voortdurend groeiende hoeveelheid black-letter law, zowel in de vorm van wet- en regelgeving als in de vorm van interne richtlijnen en EU-directieven. Daarbinnen is er een grote verscheidenheid. Sommige interne regels van overheidsorganisaties lijken op Austins bevelen ondersteund door sancties, andere normen zijn beter in de termen van Fuller te analyseren als regels die voldoen aan de beginselen van legaliteit. Vooral niet-positivistische theorieën zoals die van Fuller hebben soms moeite om die massieve hoeveelheid black-letter law met doorgaans een sterk instrumenteel karakter een plaats te geven. ${ }^{15}$

\section{De opkomst van interactief recht}

Daarnaast is er in toenemende mate ook in traditioneel publiekrechtelijke contexten veel recht met een horizontaal en interactief karakter; recht dat doorgaans is gebaseerd op min of meer horizontale en wederkerige normatieve verhoudingen. Dan gaat het om normen die voortkomen uit handelingspraktijken, uit min of meer horizontale interacties tussen verschillende partijen als burgers, bedrijven, ngo's en soms ook overheden. Jutta Brunnée en Stephen Toope hebben laten zien dat het internationaal recht het beste kan worden gezien als een netwerk van dergelijke praktijken, die zij praktijken van legaliteit noemen. ${ }^{16} \mathrm{Als}$ gevolg van de economische globalisering zijn op internationaal vlak de interacties tussen bedrijven en tussen bedrijven en staten even belangrijk als die tussen

14 Er zijn natuurlijk nog veel meer knelpunten te noemen, maar ik beperk me tot deze vier en in dit artikel dan ook nog vooral tot de eerste twee.

15 Een voorbeeld is Fullers initiële afbakening van managerial direction ten opzichte van recht, waarmee een groot deel van de administratieve black-letter law door hem eigenlijk als non-recht werd gekwalificeerd (vgl. Fuller, Morality of Law). Overigens zag Fuller in latere publicaties managerial direction wel degelijk als een legal process. Volgens Kenneth Winston zijn de vijf belangrijkste juridische processen (of 'principles of social order') in Fullers theorie contract, mediation, wetgeving, rechtspraak en managerial direction. Kenneth I. Winston, 'Introduction,' in Lon L. Fuller, The Principles of Social Order. Selected Essays of Lon L. Fuller, red. Kenneth I. Winston (Oxford: Hart Publishing 2001 [1981]), 25-58, op p. 44.

16 Jutta Brunnée \& Stephen J. Toope, Legitimacy and Legality in International Law. An Interactional Account (Cambridge: Cambridge University Press, 2010). 
staten onderling. ${ }^{17}$ De juridische structuur van deze interacties is doorgaans georganiseerd rond contracten, convenanten en andere horizontale rechtsvormen, inclusief het gewoonterecht. Op nationaal niveau zijn er tal van verschijnselen als onderhandelende en communicatieve wetgeving, zelfregulering en interne normen van medische professies, organisaties en handelspraktijken.

We kunnen dit 'interactief recht' noemen, omdat het recht voortkomt uit de interacties tussen partijen in een gemeenschappelijke praktijk of een netwerk, en niet het product is van gezaghebbende instituties. Natuurlijk bestond interactief recht in privaatrechtelijke verhoudingen altijd al in de vorm van gewoonterecht en informele contracten - twee vormen van recht waar veel filosofische theorieën niet goed raad mee weten. Maar tegenwoordig is het ook in de publiekrechtelijke sfeer een veelvoorkomend verschijnsel. Dergelijke interactieve normen passen niet goed in traditionele rechtspositivistische theorieën en worden daarom soms als niet-recht of deviant recht afgewezen door traditionele juristen. ${ }^{18}$ Hoe men het verschijnsel normatief wil beoordelen, interesseert mij in dit verband niet - ik ben alleen geïnteresseerd in een descriptieve analyse. Het gaat mij erom dat dit verschijnsel van de opkomst van interactief recht niet kan worden genegeerd en dat een adequate beschrijvende theorie van recht er plaats voor moet inruimen.

\section{Global Legal Pluralism}

Vroeger kon je nog gewoon Nederlands recht studeren, vanuit de fictie dat het om een min of meer afgesloten rechtsorde ging. Wie nu het in Nederland geldende recht wil bestuderen, heeft echter met een pluraliteit aan rechtsordes te maken die niet in een harmonieuze onderlinge hiërarchische verhouding staan: het Nederlands statelijk recht, het recht van de EU, het recht van Straatsburg, het recht van tal van internationale organisaties, maar bijvoorbeeld ook allerlei normen die binnen professionele organisaties, nationaal en internationaal, ontwikkeld zijn. Veel nieuwe rechtsordes zijn ook niet meer verbonden met een specifiek grondgebied. We kunnen dit globaal rechtspluralisme in de minimale betekenis noemen. Zelfs als men het daarbij zou willen laten en anders dan veel rechtssociologen het interne recht van praktijken en organisaties niet als recht zou willen betitelen, is het pluralisme van rechtsordes niet te ontkennen. ${ }^{19}$ Natuurlijk doen sommige handboekenschrijvers alsof uit al deze rechtsordes samen één coherente doctrine van geldend recht kan worden afgeleid, maar dat is een fictie die de inherente spanningsrelaties tussen die rechtsordes onvoldoende recht doet.

Een dergelijk minimaal rechtspluralisme op basis van verschillende officiële rechtsordes, zoals nationaal recht, EU-recht, Raad van Europa en internationaal

17 Vgl. Paul S. Berman, 'Global Legal Pluralism,' South California Law Review 80 (2007): 1155, op 1162: 'we see communities of transnational bankers developing their own law governing trade finance and the use of modern forms of lex mercatoria to govern business relations.'

18 Vgl. bijv. Sidney Richards, 'Globalization as a Factor in General Jurisprudence,' Netherlands Journal of Legal Philosophy 41 (2012): 129, op 130: 'Jurisprudence is at present, and has historically been, overwhelmingly state-centric.' 
recht is al lastig voor veel rechtstheorieën, in het bijzonder voor allerlei positivistische varianten waarin het recht direct of indirect te herleiden is tot het gezag van soevereine natiestaten. Maar rechtspluralisme is tegenwoordig in redelijkheid niet meer tot deze minimale variant te beperken. ${ }^{20}$ Het omvat tal van andere niet-statelijke rechtsordes, zoals normen ontwikkeld in 'tribal or ethnic enclaves, religious organizations, corporate bylaws, social customs, private regulatory bodies, and a wide variety of groups, associations and non-state institutions. ${ }^{21}$ Deze rechtsordes staan ook niet in een hiërarchisch verband (waardoor uiteindelijk de meeste rechtsordes misschien nog indirect tot soevereine staten zouden zijn te herleiden), maar zijn ten opzichte van elkaar relatief autonoom. Ze staan relatief los van elkaar, maar zijn deels ook met elkaar verbonden - zonder dat echter een van de rechtsordes altijd het primaat ten opzichte van de andere rechtsordes kan claimen. Dit complexe netwerk van relatief autonome rechtsordes kan in mijn ogen door geen enkele van de gangbare filosofische theorieën van recht adequaat worden geconceptualiseerd.

\section{Dynamiek}

Een laatste kenmerk is de toegenomen dynamiek van het recht. ${ }^{22}$ Niet alleen de samenleving verandert in hoog tempo, ook het recht doet dat. De traditionele methode om het recht te beschrijven is door een momentopname van de juridische doctrine te maken van het recht op een bepaalde datum, zoals blijkt uit toevoegingen in dissertaties als 'de jurisprudentie is verwerkt tot 1 januari 2014'. Maar in tijden van sterke verandering is het gevolg dat beschrijvingen van het recht hijgend achter de ontwikkelingen aanlopen. Een theorie van recht moet ook in staat zijn om de onderliggende ontwikkelingen en trends te begrijpen.

\section{Een juridisch interactionistische theorie}

Mijn stelling is dat een theorie van recht, en dus ook een theorie van recht en moraal, voor Nederland (en vergelijkbare landen) anno 2014 recht moet doen aan deze vier kenmerken. Natuurlijk zijn er nog andere relevante kenmerken, maar die laat ik buiten beschouwing. Dat kan omdat deze meer voor de hand liggende kenmerken in de gangbare theorieën doorgaans al meegenomen zijn, en ik niet de pretentie heb om los van die theorieën een geheel nieuwe theorie te bouwen. De vraag is dus of er een theorie van recht te ontwikkelen is die aan deze vier specifieke verschijnselen recht kan doen.

20 Mark Van Hoecke, Law as Communication (Oxford: Hart Publishing, 2002), 1-2, stelt zelfs: 'Today a conception of legal pluralism is widely accepted, which does not limit the law to state legal orders but broadens it to differing forms of institutionalised social organisations, such as international law, sports associations, or numerous forms of unofficial law.' Dit kan waar zijn voor rechtssociologen en Europese rechtstheoretici - in Noord-Amerika ligt het echt anders - maar ik betwijfel of onder gewone juristen en burgers een dergelijk juridisch pluralisme zo algemeen geaccepteerd is als Van Hoecke claimt.

21 Berman, 'Global Legal Pluralism,' 1172.

22 Vgl. hierover uitgebreider Wibren van der Burg, Dynamisch recht. De interactie tussen recht, ethiek en samenleving (oratie Tilburg; Den Haag: Boom Juridische uitgevers, 2001). 
Ik begin met de eerste twee kenmerken, de opkomst van black-letter law en van interactief recht. Voor het beschrijven van het eerste verschijnsel zijn positivistische theorieën redelijk geschikt, maar voor de beschrijving van het tweede schieten ze tekort. Gewoonterecht en internationaal recht worden bijvoorbeeld door de meeste positivistische theorieën slechts recht genoemd onder bepaalde voorwaarden en zelfs dan nog worden deze verschijnselen vaak als een soort tweederangsrecht gezien. ${ }^{23}$ Omgekeerd hebben theorieën als die van Selznick en Fuller in The Morality of Law veel te bieden voor de beschrijving van interactief recht, maar schieten ze tekort bij die delen van het positieve recht die vooral als hiërarchische bevelen kunnen worden gezien. ${ }^{24}$ Rubin stelt bijvoorbeeld overtuigend dat er in de moderne regulatory state veel regelgeving is die uitsluitend gericht is op grote bureaucratische overheidsinstellingen, de vorm heeft van top-down reguleringen en directieven, en daarbij vrijwel geen van Fullers acht beginselen van legaliteit belichaamt. ${ }^{25}$ Toch is er volgens hem geen reden om dit niet als recht te betitelen.

De oplossing moet gezocht worden in een theorie die zowel recht kan doen aan interactief recht als aan positief recht met een hiërarchisch top-down karakter. Ik betitel die theorie als 'juridisch interactionisme' omdat zij speciale aandacht heeft voor de betekenis van interactief recht. De eenzijdigheid van veel rechtstheorieën (met inbegrip van Fullers theorie in The Morality of Law) is dat ze proberen alles te herleiden tot slechts één bron. In juridisch interactionisme daarentegen verwijst de term 'recht' zowel naar de normen die ontstaan in praktijken van horizontale interactie, als naar door juridische autoriteiten geformuleerde normen. Maar anders dan in de variant hiervan die door Brunnée en Toope is ontwikkeld (zij spreken overigens van interactionalisme), claim ik niet dat interactief recht de enige basis is van alle recht. Waar Brunnée en Toope zich richten op het bekendste werk van Fuller, The Morality of Law, richt ik mij hier op het latere werk, dat meer pluralistisch van aard is. ${ }^{26}$

In zijn boekje Anatomy of the Law, oorspronkelijk bedoeld als een bijdrage aan een encyclopedie en daardoor meer verzoenend dan The Morality of Law, probeert Fuller recht te doen aan zowel de natuurrechtstraditie als het rechtspositivisme. Hij onderscheidt tussen twee bronnen van recht: 'enactment' en 'interaction'. ${ }^{27}$

23 Vgl. Hart, Concept of Law, 237, waar hij betoogt dat internationaal recht qua functie en inhoud voldoende lijkt op gewoon recht om recht genoemd te kunnen worden; voor een zelfstandige betekenis van gewoonterecht is bij Hart eigenlijk al helemaal geen ruimte.

24 Philip Selznick, 'Sociology and Natural Law' en Fuller, Morality of Law.

25 Edward L. Rubin, 'Law and Legislation in the Administrative State,' Columbia Law Review 89 (1989): 369.

26 Lon L. Fuller, Anatomy of the Law (New York: Praeger, 1968; Westport, CT: Greenwood Press, 1976) en Fuller, Principles of Social Order, in het bijzonder het artikel 'Human Interaction and the Law'.

27 Fuller duidt de beide typen in zijn werk op verschillende manieren aan: als implicit of interactional enerzijds en made of enacted anderzijds. Ik kies voor interactional versus enacted, en in het Nederlands 'interactief' versus 'gepositiveerd' omdat deze termen aanduiden hoe het recht ontstaat, namelijk door interactie respectievelijk positivering door een juridische autoriteit. 
Interactief recht zijn de normen voor gedrag die geleidelijk ontstaan in doorgaans min of meer horizontale handelingspraktijken. Of in termen van Fuller: een verzameling wederkerige verwachtingen die functioneren als basis voor orde tussen de partijen. ${ }^{28}$ De formulering van de norm is secundair ten opzichte van de handelingspraktijk. Postema formuleert het als volgt:

'[I]mplicit rules arise from conduct, not conception. Verbal formulations may more or less accurately capture the rules implicit in the conduct, but the formulations are always post hoc and strictly answerable to the conduct. No formulation is authoritative in virtue of its public articulation alone. Although implicit rules arise from the conduct of determinate agents, typically they have no precise date of birth and no determinate authors. They presuppose no relations of authority and subordination; thus, their practical force depends neither on authority nor on enactment, but on the fact that they find "direct expression in the conduct of people toward one another."29

Enacted law, oftewel gepositiveerd recht ${ }^{30}$, is recht dat in verticale gezagsrelaties ontstaat doordat een autoriteit een gezaghebbende formulering geeft van de normen. ${ }^{31}$ De formulering van de norm door wetgever of rechter op tijdstip $\mathrm{X}$ is dus het vertrekpunt, de handelingspraktijk is secundair. Simpel gezegd: bij interactief recht gaat de handelingspraktijk vooraf aan de verwoording; bij gepositiveerd recht gaat de verwoording vooraf aan de handelingspraktijk.

'Made rules are given canonical verbal formulations by a determinate author at a reasonably precise date. The practical force of made rules depends on the

28 Fuller, Principles of Social Order, 286. Hoewel Fuller deze formule niet presenteert als een beschrijving van implicit law, merkt David Luban terecht op dat deze prima kan worden gebruikt als definitie hiervan. (David Luban, 'Rediscovering Fuller's Legal Ethics,' in Rediscovering Fuller. Essays on Implicit Law and Institutional Design, eds. Willem J. Witteveen \& Wibren van der Burg (Amsterdam: Amsterdam University Press, 1999), 193-225, op 206.)

29 Gerald J. Postema, 'Implicit Law,' in Witteveen \& Van der Burg, Rediscovering Fuller, 255, op 257. In de laatste zin citeert hij Fuller, 'Human Interaction and the Law', in Principles of Social Order, 232.

30 Ik vertaal enacted hier met 'gepositiveerd' en niet met 'positief', omdat het uitsluitend om dat deel van het positieve of geldende recht gaat dat rechtstreeks te herleiden is tot uitspraken van gezaghebbende instituties. Afhankelijk van de aangehangen rechtstheorie omvat positief of geldend recht daarnaast ook veel andere elementen als gewoonterecht, verkeersgebruiken, rechtsbeginselen, contracten, verdragen - elementen die deels gebaseerd zijn op interactief recht en deels op constructieve interpretatie.

31 Ik ga hier uit van rechtspraak als gezaghebbende interpretatie van wetgeving, zoals in de theorie van Civil Law-tradities een gebruikelijke opvatting is, waarbij de rechter soms ook als wetgeverplaatsvervanger moet optreden. Volgens Fuller is Common Law adjudication een zelfstandige bron van recht en omvat het net als het contract elementen van enactment en interaction. Ook in Civil Law countries is rechtspraak natuurlijk niet identiek aan wetgeving en eveneens als een mengvorm van enactment en interaction te beschouwen (en dit geldt bovendien ook voor interactieve vormen van wetgeving). Om de theorie niet nodeloos nog ingewikkelder te maken, combineer ik hier wetgeving en rechtspraak in één bron, enacted oftewel gepositiveerd recht. 
authority of their makers or the offices they occupy. Thus, made rules presuppose both authors and relations of authority and subordination. ${ }^{32}$

Volgens Fuller moeten we beide als bron van recht erkennen. Daarnaast zijn er nog andere bronnen, zoals het contract, dat zowel elementen van positivering als van interactie bevat, maar ook een eigenstandige betekenis heeft. ${ }^{33}$

Het feit dat er twee (of meer) bronnen van recht zijn, betekent niet dat het geheel losstaande bronnen zijn. Integendeel, ze zijn met elkaar verweven en verwijzen naar elkaar. Uiteindelijk is er alleen recht als er een handelingspraktijk is die met de normen verbonden is. Wanneer dat niet het geval is, is er sprake van een dood rechtssysteem, zoals het klassieke Romeinse of het oud-Friese recht, of een vergeefse poging tot gezagsuitoefening door een failed state of misschien door een gek die denkt dat hij Napoleon is. Er is dus altijd de noodzaak van een band met een handelingspraktijk. Maar dat betekent niet dat positiveringen kunnen worden gereduceerd tot die handelingspraktijken. Er kunnen flinke spanningen bestaan tussen de handelingspraktijken en de in wetten en rechtspraak gepositiveerde normen en het zou onjuist zijn om de laatste alleen rechtskracht toe te kennen wanneer ze ook in de praktijk worden nageleefd. De gepositiveerde normen hebben wel minder rechtskracht wanneer ze niet overeenkomen met interactienormen, maar daarmee is die rechtskracht niet nihil. Een voorbeeld zijn sommige interne richtlijnen van overheidsbureaucratieën die in circulaires zijn vastgelegd, maar op de werkvloer nauwelijks bekend zijn en dus niet worden nageleefd. Ook dergelijke black-letter-normen die genegeerd worden, zijn verbonden met een algemene claim tot gehoorzaamheid door een gezaghebbende instantie. Zolang er een praktijk is waarin ondergeschikten dergelijke voorschriften in het algemeen wel redelijk naleven, hebben ze daarom rechtskarakter - zij het dan dat ze minder recht zijn dan normen die zowel zijn uitgevaardigd als worden nageleefd.

Ook op andere manieren zijn gepositiveerd recht en interactief recht verweven. Fullers internal morality of law is een voorbeeld. ${ }^{34}$ Wetgeving is een praktijk die ingebed is in een kader van wederkerige verwachtingen tussen burgers en wetgever. Als een wetgever effectieve normen wil uitvaardigen, veronderstelt hij dat de burgers zich als verantwoordelijke burgers opstellen, maar omgekeerd mogen de burgers ook verwachten dat de wetgever zich redelijk opstelt en aan de burgers dus geen onmogelijke of onredelijke eisen stelt. Naarmate de wetgever dit vaker toch doet en bijvoorbeeld te vaak en op te korte termijn de wet verandert of onheldere en intern tegenstrijdige normen uitvaardigt, verzwakt het gezag van de wetgever en vermindert het rechtskarakter van het recht.

33 Vgl. Fuller, Anatomy of the Law, 117. Fuller is hierin overigens niet consistent; hij presenteert het contract zowel als een mengvorm als ook als een eigenstandige rechtsbron. Ik meen dat het het beste is om het als beide te zien. 


\section{Een pluralistisch en gradueel rechtsbegrip}

Juridisch interactionisme impliceert een pluralistische visie op recht. Sommige normen zijn recht omdat ze in handelingspraktijken als recht zijn gegroeid, andere omdat ze na overeenstemming in contracten of verdragen zijn vastgelegd en weer andere omdat ze door een wetgever of rechter gezaghebbend zijn geformuleerd. Maar wat is dan het gemeenschappelijke kenmerk dat de normen in elk van die varianten tot recht maakt, en wat is het gemeenschappelijk criterium voor de gelding van recht? Mijn antwoord is dat dit gemeenschappelijk kenmerk er niet is.

We kunnen het begrip recht het beste begrijpen in termen van een dynamische familiegelijkenis. ${ }^{35}$ Een dynamische familie: er overlijden leden en er worden nieuwe leden geboren en geadopteerd. Er zijn zelfs aangetrouwde leden die tot de familie gaan behoren, zoals Koningin Máxima nu deel is van de Oranjedynastie en Jacqueline Onassis altijd deel zal blijven uitmaken van de Kennedy-clan. Er is niet één gemeenschappelijk kenmerk voor de leden van die familie en de kenmerken veranderen ook door de generaties heen. Evenzo geldt dat er niet één criterium is dat bepaalt wat recht is; er zijn een aantal alternatieve criteria en hun aantal en interpretatie is aan verandering onderhevig. Gewoonterecht was vroeger heel belangrijk, raakte in de negentiende eeuw op de achtergrond en werd door de globalisering weer belangrijker. Het is bijvoorbeeld goed voorstelbaar dat - ook al is het minder goed voorstelbaar hoe - er nieuw recht zal ontstaan voor de globale virtuele wereld, dat aan geen van de nu gangbare criteria voldoet. Het zoeken naar een begrip van recht dat zich richt op essentiële en universele kenmerken, is bij een dergelijk dynamisch en pluralistisch verschijnsel niet zinvol.

We kunnen echter wel proberen een soort ideaaltype van volledig ontwikkeld recht te construeren, onder de aantekening dat er niet slechts één ideaaltype hoeft te bestaan. ${ }^{36}$ In een interactionistische benadering is recht een normatieve orde. Deze komt voort uit wederkerige verwachtingen tussen de burgers en is geworteld in een praktijk van legaliteit. Zoals Selznick heeft betoogd, is recht een praktijk die gericht is op het ideaal van rechtsstatelijkheid. ${ }^{37}$ Maar daaraan moeten we toevoegen dat het recht ook is gericht op andere specifiek juridische idealen zoals rechtvaardigheid en niet-specifiek juridische idealen zoals demo-

Ludwig Wittgenstein, Philosophical Investigations I, transl. G.E.M. Anscombe (Malden, MA: Blackwell, 2001), nr. 67. In de literatuur over familiegelijkenissen overheerst een statisch en biologisch beeld van families, alsof het alleen om de nakomelingen van één bepaalde voorouder gaat. Het lijkt mij beter een dynamischer en niet-biologisch beeld te hanteren, waarbij ook adoptiefkinderen en partners als deel van de familie worden gezien en waarbij erkend wordt dat er in de loop der tijd nieuwe kenmerkende eigenschappen in families kunnen opduiken en andere eigenschappen geheel kunnen verdwijnen.

36 Dit is dus een ideaaltype dat ik vanuit de specifieke context van Nederland in de $21^{\text {ste }}$ eeuw heb geconstrueerd. In andere contexten zouden andere ideaaltypen geconstrueerd kunnen worden. Selznick, 'Sociology and Natural Law.' 
cratie. ${ }^{38}$ In die praktijk worden de wederkerige verwachtingen steeds sterker (of in geval van verval: zwakker) en wordt ook het institutionele karakter van het recht steeds sterker, met als gevolg het ontstaan van specifiek juridische subpraktijken zoals wetgeving en rechtspraak.

Verschillende elementen die door sommige theoretici als wezenskenmerken van recht worden voorgesteld kunnen in deze ideaaltypische schets passen. In een complexe samenleving is gewoonterecht onoverzichtelijk en is het vertrouwen op geleidelijke processen van verandering niet erg effectief. Dus moeten er expliciete regels en procedures komen om te bepalen wat de inhoud van het recht is, hoe deze kan worden veranderd en hoe het recht kan worden toegepast: Harts secundary rules of recognition, change and adjudication. ${ }^{39}$ Zowel met het oog op de rechtszekerheid als met het oog op een effectieve discussie over de inhoud van normen, is het wenselijk dat juridische normen en waarden expliciet worden geformuleerd in wetten; dus is recht meestal black-letter law, in de vorm van weten regelgeving uitgevaardigd door gezaghebbende instituties. ${ }^{40}$ De effectiviteit van het recht wordt verder vergroot als er sancties zijn en instituties bestaan die sancties toepassen en normen afdwingen. Dit draagt bij aan een congruentie tussen de officieel uitgevaardigde normen en de interactieve normen. Voor bekende criteria als secundaire regels, sancties en normen uitgevaardigd door gezaghebbende instituties is in deze ideaaltypische schets dus ook een plaats. Maar let wel: in een dergelijk ideaaltype van een ontwikkeld rechtssysteem bestaan wel juridische instituties, maar die zijn niet noodzakelijk met een staat verbonden.

Als dit een schets is van een volledig ontwikkeld rechtssysteem, ligt het voor de hand dat er meerdere manieren zijn waarop een rechtssysteem minder dan perfect kan zijn. Soms zullen sancties ontbreken, soms instituties, soms secundaire regels. Expliciete formulering van rechtsregels op papier is evenmin noodzakelijk. En de expliciet geformuleerde normen kunnen op gespannen voet staan met de normen zoals ze in de praktijk worden ervaren en gevolgd door de burgers.

In een interactionistische visie is recht daarom een gradueel begrip. Een normatieve orde kan meer of minder recht zijn. ${ }^{41}$ Als alle genoemde karakteristieken afwezig zijn, is er geen recht, maar wat er nodig is om wel van recht te spreken, kan niet in een simpele formule worden gevangen. Er zijn meerdere manieren waarop een normatieve orde een gedeeltelijk juridisch karakter kan hebben. Er is niet één universele definitie van recht mogelijk, maar natuurlijk kunnen - en

Taekema, Concept of Ideals in Legal Theory, 188 bepleit terecht dat recht niet alleen op typisch juridische idealen zoals legaliteit gericht hoeft te zijn.

39 Hart, Concept of Law.

40 Vgl. Antonie A.G. Peters, 'Law as Critical Discussion,' in Dilemmas of Law in the Welfare State, ed. Gunther Teubner (Berlin: De Gruyter 1986), 250.

41 Zowel Fuller als Selznick hebben consequent benadrukt dat recht geleidelijk kan ontstaan en ook weer geleidelijk kan verdwijnen, en dat normatieve ordes meer of minder rechtskarakter kunnen hebben. Dit gradualisme is ook een belangrijke reden waarom juridisch interactionisme recht kan doen aan rechtsontwikkeling. 
moeten - we wel voor bepaalde doelen een definitie stipuleren. Maar dat is dan ook precies wat het is: een stipulatie.

Betekent dit dan dat everything goes? Nee, want er moeten wel degelijk goede redenen worden aangevoerd om een specifieke stipulatieve definitie te kiezen, en die redenen zijn niet willekeurig, maar gerelateerd aan het doel waartoe een definitie nodig is. Een rechtssocioloog heeft vaak andere doelen voor ogen bij het onderzoeken van recht dan een jurist; voor een rechtssocioloog kan daarom een eenvoudig operationaliseerbare definitie van rechten in termen van een eenheid van primaire en secundaire regels zinvol zijn. ${ }^{42}$ In het internationale recht ontbreekt een staatsapparaat; daarom is voor het internationale recht een definitie in termen van practices of legality, zoals door Brunnée en Toope voorgesteld, goed verdedigbaar. ${ }^{43}$ Voor een Nederlandse rechter zal de nadruk liggen op normen die uitgevaardigd zijn door voor de Nederlandse burger gezaghebbende instituties zoals wetgever, rechters en internationale instellingen; herkomstregels (de bekende tests of pedigree) zijn daarom een onmisbaar onderdeel van een werkdefinitie. Er is dus niet één specifiek criterium waardoor juridische normen kunnen worden onderscheiden van andere sociale normen; het hangt af van de context en het perspectief welke afbakening zinvol is.

Uit deze benadering volgt dat recht een pluralistisch begrip is: er zijn meerdere typen normatieve orde die allemaal als recht kunnen worden aangeduid. Er is niet meer dan een dynamische familiegelijkenis. Die rechtsorde kan statelijk recht zijn, maar ook niet-statelijk recht. Binnen de staatsorganisatie kunnen verschillende relatief autonome rechtsordes bestaan, zoals de interne normen en rechtscultuur van een ministerie of een zelfstandig bestuursorgaan. En in de samenleving zijn er eveneens, zoals Fuller al verdedigde, tienduizenden relatief autonome rechtsordes, variërend van de rechtsorde die door een contractuele overeenkomst wordt geconstitueerd tot de interne normen van een voetbalclub. ${ }^{44}$ Uitdrukkelijk spreek ik echter, in navolging van Sanne Taekema, van relatief autonome rechtsordes. Elk van die rechtsordes is ingebed in een netwerk van andere rechtsordes, waarvan doorgaans die van het statelijk recht de belangrijkste is. ${ }^{45}$ Relatieve autonomie dienen we dus niet alleen te begrijpen in relatie tot de statelijke rechtsorde. Soms is er maar een zeer beperkte autonomie, zoals bij de interne normen van ministeries, soms is er een vergaande autonomie, zoals bij de interne regels van een religieuze sekte ten opzichte van het statelijk recht. Soms botsen die rechtsordes, soms convergeren ze; meestal zijn er op zijn minst geringe fricties. Ook het statelijk recht kan in verhouding tot zowel de inter- en suprana-

42 Dit verklaart ook waarom Selznick in zijn rechtssociologisch onderzoek naar industriële organisaties voor zijn minimale definitie inspiratie kon vinden in Harts criteria van aanwezigheid van secundaire regels. Zijn rechtsbegrip was veel rijker, maar voor zijn minimale definitie had hij hieraan voldoende. Philip Selznick, Law, Society and Industrial Justice (New York: Russell Sage Foundation, 1969), 5-7.

43 Brunnée and Toope, Legitimacy and Legality in International Law.

44 Fuller, Morality of Law, 125; zie ook Roderick A. Macdonald, 'Legislation and Governance,' in Witteveen \& Van der Burg, Rediscovering Fuller, 283.

45 Taekema, Concept of Ideals in Legal Theory, 189. 
tionale rechtsordes als tot de in de eigen maatschappij voorkomende rechtsordes als relatief autonoom worden gekarakteriseerd. Met andere woorden: juridisch interactionisme impliceert de acceptatie van een brede, maar tegelijk gerelativeerde vorm van rechtspluralisme. ${ }^{46}$

Maar wat betekent dit dan voor de rechter die recht moet spreken - die moet toch een duidelijk criterium hebben om te bepalen wat recht is? Deze vraag, die in reactie op mijn voordracht op de VWR in Maastricht ook door verschillende critici naar voren werd gebracht, is terecht. Maar het pluralisme dat ik hier verdedig, is het pluralisme van de theoreticus die probeert aan alle perspectieven recht te doen. Het wordt anders op het moment dat er een specifiek perspectief gegeven is. De rechter zit vast aan een dergelijk specifiek perspectief, namelijk dat van de open Nederlandse rechtsorde en is daaraan institutioneel gebonden. Hij kan dus niet anders dan vanuit dat perspectief nagaan hoe de claims van andere juridische ordes moeten worden beoordeeld. Met betrekking tot sommige normen afkomstig uit dergelijke normatieve ordes zal de conclusie zijn dat deze geïncorporeerd zijn in het Nederlandse recht; dat geldt bijvoorbeeld voor het recht van de EU, van het EVRM en van sommige andere internationale organisaties en verdragen. Van andere normen zal de rechter aangeven dat deze alleen in specifieke situaties en onder specifieke voorwaarden erkend kunnen worden als voor de betrokkenen bindende rechtsnormen. Dat geldt bijvoorbeeld voor niet-Nederlands familierecht bij een scheiding, voor contractuele bepalingen, voor sommige verkeersgebruiken en interne normen van organisaties als verenigingen en kerken en zelfs voor de standaarden van de professionele ethiek. En in weer andere gevallen zal de rechter concluderen dat de normen in strijd zijn met de Nederlandse rechtsorde en dus niet erkend kunnen worden. Dat geldt voor polygame huwelijken, sommige contractuele bepalingen en de interne normen van een maffiaclan.

De theoretische erkenning van rechtspluralisme staat een dergelijke praktische omgang daarmee door de rechter niet in de weg. Sterker nog, het werkt juist verhelderend, omdat het duidelijk maakt dat de rechter niets heeft aan een filosofisch antwoord op de algemene vraag 'Wat is recht?', maar gewoon vanuit het interne perspectief van de eigen rechtsorde een dergelijk antwoord zal moeten

46 Relatief rechtspluralisme moet worden onderscheiden van wat John Griffiths als pluralisme in zwakke zin betitelt. (John Griffiths, 'What is Legal Pluralism?,' Journal of Legal Pluralism 24 (1986): 5.) Dit laatste is de erkenning, doorgaans door een koloniale macht, van parallelle rechtsregimes voor verschillende groepen van de bevolking binnen het kader van een overkoepelende en dominante statelijke rechtsorde. Relatief rechtspluralisme is het bestaan van concurrerende rechtsordes waarbij geen van deze ordes kan claimen de overkoepelende rechtsorde te zijn. 
construeren. ${ }^{47}$ Dat doen rechters al eeuwen en daarvoor hebben ze filosofen echt niet nodig.

\section{Conclusie}

Hiermee heb ik de hoofdlijnen van een theorie van juridisch interactionisme geschetst. Mijn stelling, die ik hier niet verder kan uitwerken, ${ }^{48}$ is dat deze pluralistische theorie ook in staat is om verschijnselen te verklaren die vaak als anomalieën of op zijn minst als afwijkingen worden bekritiseerd. Voorbeelden daarvan zijn het internationaal recht (dat lange tijd niet als recht werd gezien), de doctrine van het Hof in Straatsburg dat de Europese Conventie voor de Rechten van de Mens als een living instrument moet worden gezien, en communicatieve en onderhandelende wetgeving. Bovendien geeft juridisch interactionisme ook een beter kader om de interactie tussen recht en moraal te beschrijven, in termen van twee deels verstrengelde, deels autonome normatieve ordes. Dat gezondheidsrecht en bio-ethiek twintig jaar geleden zo sterk verstrengeld waren, blijkt in dit licht achteraf geen pathologisch verschijnsel, zoals de metafoor van de Siamese tweeling suggereerde. Het was een volstrekt normale variatie - een verstrengeling die overigens intussen door een proces van codificering al weer minder intensief is geworden. De rechtstheorie dient zich sterker te richten op het begrijpen van die variatie en dynamiek in plaats van op abstracte analyses van wat al die varianten van recht mogelijk gemeenschappelijk zouden hebben. Juridisch interactionisme biedt daarvoor een vruchtbaar kader.

Dat interne perspectief is overigens voor de Nederlandse rechtsorde niet puur intern, maar een gematigd intern of een open perspectief. Omdat de Nederlandse rechtsorde relatief autonoom is, dient de rechter ook recht dat niet verbonden is aan het Nederlands statelijk recht deels te erkennen en te incorporeren. Maar de vraag welk recht wel en niet moet worden erkend en geïncorporeerd en op welke manier dat dient te gebeuren, dient te worden beantwoord op basis van uitgangspunten uit de Nederlandse rechtsorde zelf, dus op basis van dat interne perspectief. Met dank aan Thomas Riesthuis, wiens scherpzinnige opmerkingen me dwongen dit punt beter te doordenken. 